\title{
HISTOMORPHOMETRY OF THE EPIDIDYMAL REGION OF DOMESTIC Quail (Coturnix coturnix) OF THE ITALIAN VARIETY
}

\author{
HISTOMORFOMETRIA DA REGIÃO EPIDIDIMÁRIA DE CODORNA DOMÉSTICA \\ (Coturnix coturnix) DA VARIEDADE ITALIANA
}

\section{Antonio Marcos ORSI ${ }^{1}$; Karina SIMOES ${ }^{2}$; Maíra Aparecida STEFANINI ${ }^{3}$; Maria José Salete VIOTTO ${ }^{4}$}

1. Departamento de Anatomia, Instituto de Biociências, Universidade Estadual Paulista Júlio de Mesquita Filho, Campus de Botucatu, Botucatu, SP, Brasil; 2. Departamento de Morfologia, Instituto de Ciências Biologicas, Universidade Federal de Goiás Campus Samambaia, Goiania, GO, Brasil. simoesk@ufg.br ; 3. Departamento de Morfologia e de Patologia, Universidade Federal de São Carlos, São Carlos, SP, Brasil; 4. Departamento de Morfologia e de Patologia, Universidade Federal de São Carlos, São Carlos, SP, Brasil.

\begin{abstract}
Epididymal region of domestic adult quail of the italina variety was studied by morphometric analysis concerning to the proximal and distal efferent ductules and the epididymal duct. They formed the proper segmental epididymal region structure in domestic quail prior observed during the four seasons of the year in the Botucatu city/SP/Brazil (22 53 '09' S, 48 26 '42' 'W, 840m), with tropical altitude climate, average annual temperature of 20,7 degrees. Parameters such as the tubular diameter and the luminal diameter, structure of the lining epithelium and luminal content, of all tubules of the epididymal region, were analyzed referring each segmental tubular area disposed along the epididymal region. It was verified that the efferent ductules occupied the major proportional distribution inside the epididymal region and plus the epididymal duct presented striking quantitative and qualitative variations during the autumn and spring. These seasons respectively represented the quiescent and active phases of this quail annual testis cycle. During summer and winter some variations of the epididymal region morphology were verified. Morphological data obtained in winter and in summer respectively allow characterizing them as intermediary phases of the annual reproductive cycle. However, no remarkable change in the proximal efferent ducts and distal efferent ducts was observed in winter and summer, for the spring events, such as already described during the annual testicular cycle of domestic quail. So the epididymal region of the domestic quail of the Italian variety is a single organ, whose size varies in the autumn, with minor relative average, and in the other seasons in which this organ maintain its usual dimensions.
\end{abstract}

KEYWORDS: Epididymal region. Adult quail. Histomorphometry. Seasonal variation.

\section{INTRODUCTION}

The quail (Coturnix coturnix) belongs to the family Phasianidae of the galliform order, a taxonomic group in which other game species such as red partridges, moths and pheasants are found, being that the composition of the genus Coturnix is a cause of confusion regarding particularly the number of species (LUCIO, 1999).

The histophysiology of the testicular excurrent ducts of birds generally allow classifying them in proximal efferent ductules (PED), connective ductules, distal efferent ductules (DED), ductus epididymidis (DE) and vas deferens. The PED were preceded by the extratesticular rete testis (RT), as well as the vas deferens succeeded the DE. This pattern from epidydimal region (ER) tubules had been characterized in several species of birds (TINGARI, 1972, 1973; HESS et al., 1976; AIRE, 1979a, 1979b, 1980; LAKE, 1981; STEFANINI et al., 1999a, 1999b), including the Coturnix coturnix japonica (AIRE, 1979b; CLULOW; JONES, 1982, 1988), and Coturnix coturnix (ORSI et al., 2007a, 2007b, 2008).
Although, it was verified a scarce contribution on quantitative parameters in those studies, perhaps except for a contribution made in pigeon (STEFANINI et al., 1999a).

Thus, one aiming of this paper was to contribute from the knowledge of some quantitative parameters of quail ER observed as one entire organ. Its importance had been valorized referring to dynamic processes of maturation, storage, emission and survival of spermatozoa, before the ejaculation (STEFANINI et al., 1999a).

The spermatozoa acquire these properties inside the luminal compartments of the ER such was reported by Clulow and Jones (1982; 1988), and Stefanini et al. (1999a), although, the complete maturation of spermatozoa in birds was completed only during the vas deferens transit (TINGARI, 1973; STEFANINI et al., 1999a).

This paper also deals with some peculiarities on the structure from epithelium cell heights; tubular and lumen diameters of all the ER tubules presented in Italian quail variety. Although, in previous papers had been characterized that the main physiologic role from the epithelium cells 
lining of the RT, PED, DED and DE had been marked by occurrence of active processes of phase fluid endocytosis and adsorptive endocytosis. Both functions concerned to fluids and submycrospic solutes turnover verified in mammals (ROBAIRE; HERMO, 1988), and in some birds (STEFANINI et al., 1996, 1999a, 1999b; OZEGEB et al., 2006; ORSI et al., 2007a, 2007b, 2008; VIEGAS et al., 2011).

A cyclic pattern from the male sexual activity in the domestic quail of Italian variety (Coturnix coturnix) was described, having base on the spermatogenesis kinetics of this bird (BARALDI-ARTONI et al., 1997, 1999). Nevertheless, in the Italian quail variety the spermatogenesis kinetics showed a seasonal "circum-annual" cyclic pattern from the testis histology (ORSI et al., 2005). Seminiferous tubules behavior (ORSI et al., 2005), showed a similar pattern verified along the excurrent ducts of the testis, including the entire ER (ORSI et al., 2007a, 2007b, 2008), and into the epithelium lining and luminal compartment of the vas deferens (VIEGAS et al., 2011). Also, the testis somatic index from the Italian quail (ORSI et al., 2005), reinforced those concept of a "semi cyclic" annual testicular cycle occurring in this species (ORSI et al., 2005).

Four distinct phases had been characterized for the quail male sexual cycle being identified as an active or proliferative phase observed in the spring, a regressive phase verified in summer, a quiescent or recessive phase noted in autumn and a recrudescent phase reported in winter with tropical altitude climate in the Brazil (ORSI et al., 2005; ORSI et al., 2007a, 2007b, 2008). On the other hand, the quiescent phase observed on the fall presented small durability, comprising approximately 30 days distributed between the last fifteen days of March and the first fifteen days of April. During the other days of the autumn and in the other seasons the spermatogenesis kinetic was preserved (ORSI et al., 2005, 2007a, 2007b, 2008).

Additionally, the dynamic processes occurring in the testis and in its excurrent ducts, e.g., in the tubular complex of the ER were preserved, except from the striking morphological variability that occurred along the seminal pathway of Italian quail in the autumn (ORSI et al., 2005, 2007a, 2007b, 2008). On the base those occurrences it was classified the male sexual reproductive cycle as a semi cyclic pattern (ORSI et al., 2005), whose behavior was similarly verified in other birds including the own quail (BREUCKER et al., 1989; GUYOMARCH; GUYOMARCH, 1992; WINGFIELD et al., 1994).
Thus, having theoretical support in morphologic and physiologic studies on the seminal pathway of birds, the aim of this report was to analyze epididymal region of domestic adult quail of the italina variety by morphometric analysis, concerning to the proximal and distal efferent ductules and the epididymal duct, contributing for an overall knowledge of the domestic quail (Coturnix coturnix). Descriptions prior focused morphometric variations referring to the quail tubular ER, as well as based on marked epithelium lining fine structure occurrences verified in each season of the year.

\section{MATERIAL AND METHODS}

Were utilized 24 adult domestic quails of the Italian variety, male, with approximately 50 days, whose sexual maturity was obtained and accomplished on captive laboratorial conditions at UNESP Campus of Botucatu, (22 $53^{\prime} 09^{\prime}$ 'S, $48^{\circ} 26^{\prime} 42^{\prime}$ ' $\mathrm{W}, 840 \mathrm{~m}$ ), with tropical altitude climate, average annual temperature of 20,7 degrees, and two distinct seasons of the year: hot and rainy summer and dry winter. The quails feeding water and appropriate solid food (bird ration), administrated "ad libitum". The quails remain under natural illumination. Males were maintained in proximity with female Italian quails also captive in similar conditions, but having no direct contact among males and females during one complete year. Afterwards, 6 quails were taken in each season of the year and euthanatized, being two birds in each month of each year seasons, such as during the months of December, January and February (Summer), March, April and May (Autumn), June, July and August (Winter) and September, October and November (Spring).

The quails were euthanatized using a mixture of ketamine hydrochloride $(20 \mathrm{mg} / \mathrm{kg})$ and xylazine hydrochloride $(1,5 \mathrm{mg} / \mathrm{Kg})$ intraperitoneally applied, and conducted for dissection of their abdominal regions. The couple formed by the testis and the epididymal region (ER), comprising the efferent ductules and epididymal duct, and also the first segment of the vas deferens were collected. Previously, each quail was perfusing by a fixative solution of Karnovsky.

Before of the perfusion, adequate ER transversal sections with 1.5 to $2 \mu \mathrm{m}$ thickening (histological slides), of the proximal and distal efferent ductules and of the epididymal duct were destined for morphological studies. ER tubules from materials collected in all the seasons were placed on slides and stained by HE, Masson's and Mallory trichromes (LILLIE, 1965). Slides were conducted 
from a Zeiss Axophot ${ }^{\circledR}$ optical microscope and destined for morphometric studies. It was focused three parameters being the tubular diameter, luminal diameter and height of the tubular lining epithelium of each tubule focused. The numeric values were obtained in micrometers $(\mu \mathrm{m})$, and afterwards were obtained the medium averages of them.

The morphometric data including measures of the total ER were obtained using a Zeiss KS-300 ${ }^{\circledR}$ analysis system being analyzed three slides by each bird, containing each slide three histological sections and were made four measures by section. The results were treated by parametric analysis (MORRISON, 1976), being made prior calculus from variance analysis, arithmetic media and standard error followed by aggregation of numeric data per each season of the year.

\section{RESULTS AND DISCUSSION}

The epididymal region (ER) in Italian quail appeared as a thin and somewhat long organ mainly disposed on the dorsal margin of the respective testis having medium averages of $1.8 \pm 0.3 \mathrm{~cm}$ of length per $0.3 \pm 0.15 \mathrm{~cm}$ of width. Except in quails euthanatized in the autumn the ER appeared minor, showing medium average of $0.9 \pm 0.2 \mathrm{~cm}$ of length and a very small width approximately having $0.1 \mathrm{~cm}$ in this dimension. A similar pattern of ER macroscopic parameters was verified in the pigeon, regarding species specific differences. Those parameters were viewed also during the four seasons of the year (STEFANINI et al., 1999a, 1999b).

Histological ER was marked by a sequence of small sequential convoluted tubules which were delimited by the epididymal connective matrix and confined by a thin enveloping tunica which contain the entire tubular complex. On the ER of quail were characterized in disposition followed from cranial to caudal this sequence of ductules: tubules of the extratesticular rete testis (RT), proximal efferent ductules (PED), distal efferent ductules (DED), the proper ductus epididymidis (DE), and continuous from the caudal region of ER prolonged the proper vas deferens (Figure 1). This tubular microscopic sequence was similarly verified previously in other birds (BUDRAS, SAUER, 1975; BUDRAS; MEIER, 1981; STEFANINI et al., 1999a, 1999b; SIMÕES et al., 2004). Apparently, had been described a repetitive general pattern on the tubular ER disposition, but some authors had divided the ER in two main marked segments characterizing prior the proximal and distal efferent ductules (AIRE, 1979a, 1979b, 1980; STEFANINI et al., 1999b; OZEGEB et al., 2006).

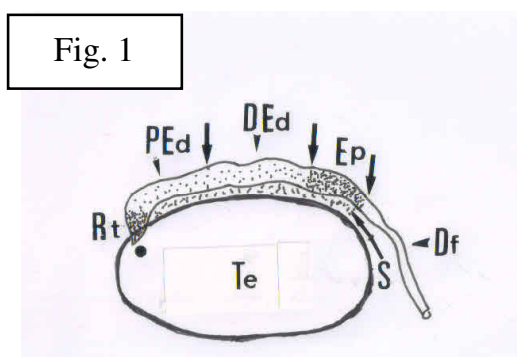

Figure 1. Schematic drawing of the quail epididymal region showing the following anatomic structures: testis $(\mathrm{Te})$, extratesticular rete testis (Rt), proximal efferent ductules (PEd), distal efferent ductules (DEd), epididymal duct (Ep), and vas deferens (Df). Size: $2 \mathrm{X}$.

Perhaps, the last emphasized disposition of the ER tubules (Rt, PEd, DEd, Ep) could be a consequence of the proportional tubular disposition along the microscopic architecture. So in quail's ER it was verified a major predominance of PED and DED occupying approximately $70 \%$ of the entire organ. They were followed by minor averages of the other tubules whose occupational area comprised $5 \%$ from the RT and $25 \%$ from the ductus epididymidis. It transmitted one inner thin and straight segment of the vas deferens, which externalize caudally since the ER limits (Figure 1). In the pigeon had been characterized that the PED and DED occupy the main area into the ER. This information had base on the tubular and luminal diameters of the tubules (STEFANINI et al., 1999b).

On the PED structure was verified the minor median values for the epithelial heights, tubular diameters and luminal diameters during the autumn (Figure 2). Also, a similar pattern to the same parameters was observed concerning to the DED and DE in other seasons (Figures 3, 4). However, the DED tubular diameters appeared higher, despite of a lower median values verified to the epithelial heights and luminal diameters hitherto observed (Figure 3). 




Figure 2. Graphic showing the medium averages in $\mu \mathrm{m}$ (ordinate), from the epithelial height (white), tubular diameter (black), and luminal diameter (gray), respectively, from the quail proximal efferent ductules, (in abscissa) showed during the year seasons being: the autumn, winter, spring and summer, respectively.



Figure 3. Graphic showing the medium averages in $\mu \mathrm{m}$ (ordinate), from the epithelial height, tubular diameter, and luminal diameter, respectively, from the quail distal efferent ductules, (abscissa) showed during the year seasons being: the autumn, winter, spring and summer, respectively.

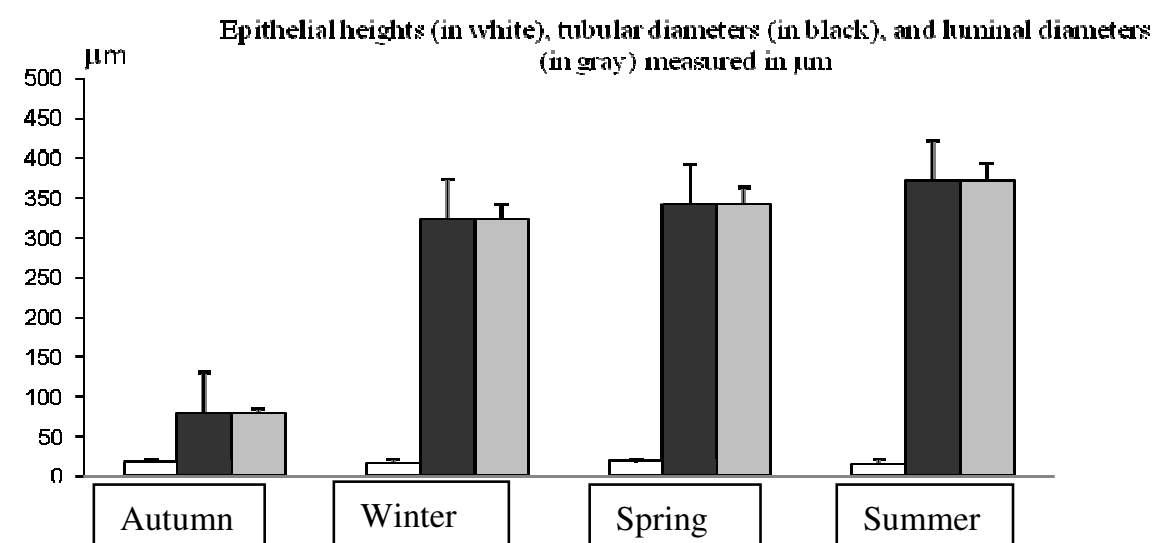

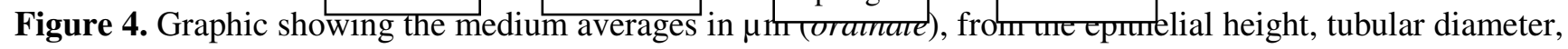
and luminal diameter, respectively, from the quail epididymal duct, (abscissa) showed during the year seasons being: the autumn, winter, spring and summer, respectively. 
Probably these observations characterized the plus marked phase of the sexual cycle whose description was made previously in this bird (ORSI et al., 2005, 2007a, 2007b, 2008). Additionally, some tubular modifications at autumn were previously described on the specific architecture of the excurrent ducts of the testis in this species according to the last references cited (ORSI et al., 2008).

During the months of spring the median values of epithelial heights, tubular diameters and luminal diameters of the quail efferent ductules (PED - Figure 2 and DED - Figure 3), showed an equilibrated numerical pattern. Epithelial heights showed minor values, luminal diameters showed medium values and tubular diameters appeared with major numerical values in terms of arithmetic media (Figures 2, 3). Spring had been characterized as the active phase of the sexual cycle in Italian quail, when the spermatogenesis kinetics was in its plenitude (ORSI et al., 2005).

Also the vector tubules from the testes emitted great amounts of spermatozoa in direction to the vas deferens in domestic pigeon and domestic quail (STEFANINI et al., 1996, 1999a, 1999b; ORSI et al., 2007a, 2008, VIEGAS et al., 2011). According to Stefanini et al. (1996, 1999a, 1999b) in domestic pigeon, and also in domestic fow (TINGARI, 1972, 1973; BUDRAS; SAUER, 1975); in turkey (HESS et al., 1976); in Japanese quail (AIRE, 1979a, 1979b, 2007; CLULOW; JONES, 1982, 1988); in ostrich (BUDRAS; MEIER, 1981), the real site in which the spermatozoa maturation and storage had been considered in birds was the vas deferens. This hypothesis had been specifically considered by Tingari (1973), as a typical function of the vas deferens in domestic fowl (Gallus domesticus).

On the other hand, the proper epididymal duct (DE) inside the ER of Italian quail, showed complexes patterns from all the parameters analyzed and previous described (ORSI, et al., 2007a, 2007b, 2008). Except in the fall that is the quiescent phase of the sexual cycle of Italian quail, when all the parameters presented low values on the other seasons of the year, a similar repetitive behavior to the tubular diameters and luminal diameters from DE were seen. All the median values from those analyzed parameters in all the three more or less active phases of the cycle comprising the winter, spring and summer (ORSI et al., 2005), permitted to verify high values from tubular and luminal diameters of the epididymal duct.

Probably, to explain those discrepant found values, comparatively, to the other tubules analyzed, three hypothesis would be considered: (H1) occurrence of a little participation of the ED on the dynamic of spermatozoa emission and modification which really occurred inside the efferent ductules; (H2) dynamic processes of spermatozoa emission and ejaculation could be roles exerted mainly by the vas deferens, acting as a "muscle pump" similarly to the proposition of Pabst (1969) made for man, and also considered by Tingari (1971) concerning the vas deferens function in domestic fowl, and (H3) perhaps the proper duct epididymis in quail was only an "inactive site" from passive transit of spermatozoa, exerting little or none influence on the spermatozoa transportation.

\section{CONCLUSIONS}

The epididymal region (ER) of the Italian domestic quail is a single organ, whose size varies in the autumn, with minor relative average, and in the other seasons in which this organ maintain its usual dimensions.

Autumn is the quiescent phase of the male sexual cycle (MSC) and spring is the proliferative phase of the MSC in this bird. The other seasons are intermediary, but also actives phases of the MSC, in which the spermatogenesis and transportation of spermatozoa along the vector ducts of the testis do not ceased.

Referring to the general morphology and in the morphometry of the proximal efferent ducts, distal efferent ducts and epididymis proper duct which are the histological components of the quail's ER suffered marked differences mainly in the autumn and spring that are considered extreme seasons of the year relatively to the dynamic functions verified inside the testis and into the excurrent ducts of the testis.

\section{ACKNOWLEDGEMENTS}

\section{We thank the grants from $\mathrm{CNPq}$} (Brasília, Brazil), and FAPESP (Sao Paulo, Brazil).

RESUMO: A região epididimária, de codorna doméstica macho adulta da variedade Italiana, foi estudada utilizando-se de análises morfométricas dos dúctulos eferentes proximais; dos dúctulos eferentes distais e do ducto epididimário. Estes dúctulos que formam a própria estrutura segmentar da região epididimária da codorna doméstica foram 
observados nas quatro estações do ano, na cidade de Botucatu/SP/Brasil (22 53 '09' 'S, 48²6'42', W, 840m), com clima tropical de altitude, média anual de temperatura de 20,7 graus. Parâmetros tais como: o diâmetro tubular e o diâmetro luminal, estrutura do epitélio de revestimento e do conteúdo luminal, de todos os túbulos da região epididimária, foram analisados referindo-se a cada zona segmentar da região epididimária. Verificou-se que os dúctulos eferentes, em conjunto, ocupam a maior área proporcional no contexto da região epididimária e junto com o ducto epididimário apresentam marcantes variações quantitativas e qualitativas, especialmente visíveis durante o outono e a primavera. Estas estações representam, respectivamente, a fase quiescente e a fase proliferativa do ciclo sexual masculino dessa ave. Os dados morfológicos obtidos no inverno e no verão, respectivamente, possibilitaram caracterizá-los como fases intermediárias do ciclo reprodutivo nesta espécie. Contudo, nenhuma variação marcante nos dúctulos eferentes proximais e dúctulos eferentes distais foi verificada no inverno e no verão, relativamente aos eventos de primavera, tal como já fora descrito durante o ciclo testicular anual da codorna doméstica. Então a região epididimária da codorna doméstica da variedade italiana é um único órgão, cujo tamanho varia no outono, com menor média relativa, e nas outras estações o órgão mantém suas dimensões usuais.

PALAVRAS-CHAVE: Região epididimária. Codorna adulta. Histomorfometria. Variação sazonal.

\section{REFERENCES}

AIRE, T. A. Micro-stereological study of the avian epididymal region. J. Anat., Malden, v. 129, p. 703-706, 1979a.

AIRE, T. A. The epididymal region of the Japanese quail (Coturnix coturnix japonica). Acta Anat., Porto, v. 103, p. 305-312, 1979 b.

AIRE, T. A. The efferent ductules of the epididymal region of birds. J. Anat., Malden, v. 130, p. 707$723,1980$.

AIRE, T. A. Reproductive biology and phylogeny of birds. 1.ed. New Haven: United States of America Publishers, 2007. 347p.

BARALDI-ARTONI, S.; ORSI, A. M.; CARVALHO, T. L.; LOPES, R. A. The annual testicular cycle of the domestic quail (Coturnix coturnix japonica). Anat. Histol. Embryol., Berlin, v. 26, p. 337-339, 1997.

BARALDI-ARTONI, S.; ORSI, A.M.; CARVALHO, T. L.; VICENTINI, C. A.; STEFANINI, M. A. Seasonal morphology of the domestic quail (Coturnix coturnix japonica) testis. Anat. Histol. Embryol., Berlin, v. 28, p. 217-220, 1999.

BREUCKER, H.; SCHAFER, E.; OBREGON, E. B. Spermatogenesis of Lophonetta specularioides (Anatidae, Aves) in the high plateau of the southern Andes. A light and electron microscopic study. Micr. Electr. Biol. Cel., Nova Jersey, v. 13, p. 167-182, 1989.

BUDRAS, K.; SAUER, T. Morphology of the epididymis of the cock (Gallus domesticus) and its effect upon the steroids sex hormones synthesis: I. Ontogenesis, morphology and distribution of the epididymis. Anat. Embryol., Berlin, v. 148, p. 175-196, 1975. https://doi.org/10.1007/BF00315269

https://doi.org/10.1007/BF00315268

BUDRAS, K; MEIER, U. The epididymis and its development in ratite birds (Ostrich, Emu, Rhea). Anat. Embryol., Berlin, v. 162, p. 281-299, 1981. https://doi.org/10.1007/BF00299973

CLULOW, J.; JONES, R. C. Production, transport, maturation, storage and survival of spermatozoa in the male Japanese quail (Coturnix coturnix japonica). J. Reprod. Fertil., Tehran, v. 64, p. 259-266, 1982. 
CLULOW, J.; JONES, R. C. Studies of fluid and spermatozoa transport in the extra testicular genital ducts of the Japanese quail. J. Anat., Malden, v. 157, p. 1-11, 1988.

GUYOMARCH, C.; GUYOMARCH, J. C. Sexual development and free-running period in quail kept in constant darkness. Gen. Comp. Endocrinol., Oxford, v. 96, p. 103-110, 1992.

HESS, R. A.; THURSTON, R. I.; BIELLIER. H. V. Morphology of the epididymal region and ductus deferens of the turkey (Meleagris gallopavo). J. Anat., Malden, v. 122, p. 241-252, 1976.

LAKE, P. E. Male genital organs. In: KING, A. S.; MCLELLAND, J. (Ed.). Form and function in birds. London: Academic Press, 1981. pp. 1-62.

LILLIE, R. D. Histopatlogic technic and practical histochemistry. 1 ed. London: Mc Graw-Hill, 1965. 715p.

LUCIO, A. J. La codorniz, Habitat, razas, selección y orientación productiva. In: BUXADÉ, C. C; ACERO, P. A. (Ed.). Explotaciones cinegéticas y de Avestruces. Madri: Ediciones MundiPrensa, 1999. pp. 87-95.

MORRINSON, D. F. Multivariate statistical methods. 1 ed. Tokyo: Kogakusha, 1976. 120p.

ORSI, A. M.; STEFANINI, M. A.; VIEGAS, K. A. S.; SIMOES, K.; BARALDI-ARTONI, S. Aspectos morfológicos do ciclo testicular anual da codorna doméstica (Coturnix coturnix), da variedade Italiana. Braz. J. Vet. Res. Anim. Sci., São Paulo, v. 42, p. 163-170, 2005.

ORSI, A. M.; STEFANINI, M.A.; VIEGAS, K. A. S.; SIMOES, K.; DOMENICONI, R. F.; MATHEUS, S. M. M. Estrutura microscópica do complexo tubular rede testicular e dúctulos eferentes proximais do testículo em codorna doméstica (Coturnix coturnix). Vet. Not., Uberlândia, v. 13, p. 1729, 2007a.

ORSI, A. M.; DOMENICONI, R. F.; STEFANINI, M. A.; BARALDI-ARTONI, S. Variabilidade sazonal no ducto epididimário de codorna doméstica: observações morfológicas. Pesq. Vet. Bras., Seropédica, v. 27, p. 1-9, 2007 b.

ORSI, A. M.; DOMENICONI, R. F.; SIMOES, K.; BEU, C. C. L.; STEFANINI, M. A. Variação sazonal na morfologia dos ductos eferentes distais em codorna doméstica mantida em cativeiro experimental. Ciênc. Rural, Santa Maria, v. 38, p. 1643-1649, 2008. https://doi.org/10.1590/S010384782008000600023

OZEGBE, P. C.; AIRE, T. A.; SOLEY. J. T. The morphology of the efferent ducts of the ostrich, a primitive bird. Anat. Embryol., Berlin, v. 211, p. 559-565, 2006. https://doi.org/10.1007/s00429-006-0107-z

PABST, R. Untersuchungen über Bau und Funktion des Menschilichen Semenleiters. Z. Anat. Entwick. Gesch., Berlin, v. 129, p. 154-176, 1969.

ROBAIRE B.; HERMO, L. Efferent ducts, epididymis, and vas deferens: structure, functions and their regulation. In: Knobil E.; Neill J.D. (Ed.). The Physiology of Reproduction. New York: Raven Press, 1988. pp. 999-1080. 
SIMOES, K.; ORSI, A. M.; ARTONI, S. M. B..; CRUZ, C.; SCHIMMING, B. C.; PINHEIRO, P. F. F. Structural features of the epididymal region of the duck (Anas plathyrynchus). Braz. J. Vet. Res. Anim. Sci., São Paulo, v. 41, p. 92-97, 2004.

STEFANINI, M. A; VICENTINI, C. A.; ORSI, A. M.; VICENTINI, I. B. F.; ARTONI, S. M. B. Características morfológicas do ducto deferente do pombo (Columba livia, L.). Rev. Bras. Biol., São Carlos, v. 56, p. 605-612, 1996.

STEFANINI, M. A.; ORSI, A. M.; GREGORIO, E. A.; VIOTTO, M. J. S.; ARTONI, S. M. B. Morphologic study of the efferent ductules of the pigeon (Columba livia). J. Morphol., Malden, v. 242, p. 247-255, 1999a.

STEFANINI, M. A.; ORSI, A. M.; CROCCI, A. J.; PADOVANI, C. R.; VICENTINI, C. A.; AIRES, E. D. La region epididimária de la paloma (Columba livia): analisis morfologico y morfometrico. Rev. Chil. Anat., Temuco, v. 17, p. 21-25, 1999 b.

TINGARI, M. D. The fine structure of the epithelial lining of the excurrent duct system of the testis of the domestic fowl (Gallus domesticus). Q. J. Exp. Physiol., London, v. 57, p. 271-295, 1972.

TINGARI, M. D. Observations on the fine structure of spermatozoa in the testis and excurrent ducts of the male fowl, Gallus domesticus. J. Reprod Fert., Tehran, v. 34, p. 255-265, 1973.

VIEGAS, K. A. S.; ORSI, A. M.; DOMENICONI, R. F.; MATHEUS, S. M. M.; SCHIMMING, B. C. Variações sazonais na ultraestrutura do ducto deferente de codorna doméstica (Coturnix coturnix).

Vet. Not., Uberlândia, v. 17, p. 66-76, 2011.

WINGFIELD, J. G.; WHALING, C. S.; MARLER, P. The Physiology of Reproduction. 2 ed. New York: Raven Press, 1994. 1434p. 